Sympozjum

Rok XXIV 2020, nr 2(39), s. 141-159

\author{
ks. Dawid Galanciak \\ Łasin \\ ORCID: 0000-0002-0113-2756; e-mail: dawidgal@op.pl \\ https://doi.org/10.4467/25443283SYM.20.024.12955
}

\title{
SŁUGA BOŻY KS. JAN LESIŃSKI (1908-1940)
}

\section{THE VENERABLE PRIEST JAN LESIŃSKI (1908-1940)}

\begin{abstract}
Abstrakt
Począwszy od pierwszych wieków swego istnienia aż po dzień dzisiejszy, Kościół naznaczony jest świadectwem wiary i krwi ludzi różnych stanów. We współczesnej historii czas drugiej wojny światowej jest tego najmocniejszym znakiem. Jednym z męczenników tego okresu, którego należy ocalić od zapomnienia, jest sługa Boży ks. Jan Lesiński. Artykuł przedstawia postać tego męczennika i formy jego upamiętnienia w społeczności, z której się wywodził. Pokazuje jednocześnie wartość tego kapłana zarówno dla więźniów obozu, w którym przebywał, jak i dla społeczności szkolnej, której jest patronem.
\end{abstract}

Słowa kluczowe: ks. Jan Lesiński, męczennicy drugiej wojny światowej, Szkoła Podstawowa w Słupie, beatyfikacja męczenników

\section{Abstract}

Since the beginning of the first centuries of its existence the Church has been marked with the witness of faith and blood of people representing 
different social classes. In contemporary history the time of the Second World War is the strongest sign of it. One example of martyrs of this period, who should be saved from oblivion is the Venerable priest Jan Lesiński. The article presents the character of the martyr and the form of his commemoration in the society he derived from. It shows the value of the priest both for the prisoners of the camp he stayed in and for the school society of which he is a patron now.

Keywords: priest Jan Lesiński, the martyrs of the Second World War, Primary School in Słup, the beatification of martyrs

\section{Wstęp}

Budując przyszłość, nie wolno zapominać o przeszłości i ludziach, którzy pisali historię świata i Kościoła przed nami. Istnieje w związku z tym potrzeba ocalenia ich od zapomnienia. Wśród tych ludzi jest sługa Boży ks. Jan Lesiński. Potrzeba ta jest tym bardziej ważna, że jak przypomina na progu nowego tysiąclecia św. Jan Paweł II: „Kościół pierwszego tysiąclecia zrodził się z krwi męczenników. (...) U kresu drugiego tysiąclecia Kościół znowu stał się Kościołem męczenników. Prześladowania ludzi wierzących - kapłanów, zakonników i świeckich - zaowocowały wielkim posiewem męczenników w różnych częściach świata. Świadectwo dawane Chrystusowi aż do przelania krwi stało się wspólnym dziedzictwem zarówno katolików, jak prawosławnych, anglikanów i protestantów. (...) To świadectwo nie może zostać zapomniane"1. Niniejszy artykuł jest jedną z form utrwalenia pamięci o kapłanie Janie Lesińskim wywodzącym się z maleńkiej wioski, która wchodziła niegdyś w skład dekanatu łasińskiego, a obecnie radzyńskiego na terenie diecezji toruńskiej. Ów kapłan jako patron szkoły w jego rodzinnej miejscowości przez świadectwo swego życia i męczeństwa jest znakiem od Boga nie tylko dla mieszkańców wsi Słup i społeczności szkolnej, ale także dla Kościoła diecezjalnego i powszechnego.

1 Jan Pawe II, List apostolski Tertio millennio adveniente, Rzym 1994 (dalej: TMA), 37. 


\section{Zarys historii parafii w Słupie}

Informacja o istnieniu miejscowości Słup pojawia się w źródłach już w 1256 roku. Początki parafii datowane są na koniec XIII wieku, jednak nie wiadomo, pod jakim wezwaniem był ówczesny kościół parafialny. Prawdopodobnie podczas wojny trzynastoletniej zniszczono kościół w Słupie, parafia straciła samodzielność i stała się częścią parafii w pobliskiej Grucie. Pobudowano jednak w tym czasie w Słupie kaplicę, której patronką była św. Anna. Niestety kaplica podupadła, dlatego w 1937 roku z inicjatywy proboszcza z Gruty ks. Władysława Fischoedera wybudowano nową kaplicę i na mocy dekretu biskupa chełmińskiego Stanisława Wojciecha Okoniewskiego ponownie erygowano z dniem 26 czerwca 1939 roku nową parafię w Słupie pod wezwaniem św. Anny. Kaplica została poświęcona w dzień Bożego Narodzenia przez ks. Franciszka Podlaszewskiego, ówczesnego dziekana dekanatu radzyńskiego ${ }^{2}$. Konsekracja kościoła i ołtarza posoborowego odbyła się dopiero 24 maja 1981 roku. Konsekratorem był biskup pomocniczy chełmiński Zygfryd Ignacy Kowalski (1910-1995). Pierwszym administratorem parafii był ks. Józef Koszałka, który pełnił posługę w Słupie do 1957 roku, będąc jednocześnie proboszczem parafii Linowo ${ }^{3}$.

\section{Miejsca pamięci na cmentarzu w Słupie}

$\mathrm{Na}$ cmentarzu parafialnym w Słupie znajdują się dwa miejsca pamięci. Pierwsze $\mathrm{z}$ nich umieszczone jest na końcu alejki ciągnącej się od bramy cmentarnej. Poświęcone jest ono jeńcom radzieckim. Do dużego kamienia przymocowana jest płyta z napisem: „ "Pamiętamy i będziemy pamiętać». Bezimiennym jeńcom radzieckim rozstrzelanym 6 czerwca 1944 roku. Mieszkańcy 1 września 2005”. Drugie miejsce pamięci znajduje się po prawej stronie krzyża cmentarnego. Pod drzewami znajduje się odnowiona tablica przymocowana do kamienia. Fundatorami odno-

2 Por. W. Miszewski (red.), Diecezja Toruńska. Spis parafii i duchowieństwa. Rok 2002, Toruń 2002, s. 464.

3 Por. Historia Parafii, „Gazetka parafialna” 26.07.1999, s. 2. 
wionego miejsca pamięci, zgodnie z napisami umieszczonymi na płycie stanowiącej podstawę dla kamienia, są mieszkańcy wsi Słup i wójt gminy Gruta. Odnowienia dokonano 25 września 2016 roku. Nad tablicą umieszczono polskiego orła wojskowego w koronie, a po prawej stronie odlew kwiatu róży. Na tablicy widnieje napis: „W hołdzie Mieszkańcom Parafii św. Anny w Słupie, którzy życie swe oddali za wolność i niepodległość, abyśmy mogli być Polakami i żyć w wolnej i niepodległej Ojczyźnie. Pomordowanym przez Niemców i poległym na przestrzeni lat 1939-1945, znanym i tym wszystkim anonimowym, których kryje historia. Mieszkańcy - Parafianie. Słup - Jasiewo”. Poniżej, na tablicy, znajdują się nazwiska: sługa Boży ks. Jan Lesiński, Angowska Anna, Angowski Wawrzyniec, Cieszyński Bernard, Fedrau Bronisław, Frączek Józef, Górny Aleksander, Kufel Teofil, Kurzyński Franciszek, Mazurek Jan, Mieszczanek Joanna, Mieszczanek Henryk, Mijewski Jan, Mijewski Konstanty, Müller Bolesław, Pyszora Konrad, Robaczewski Konstanty, Wojtaszewski Antoni, Wojtaszewski Franciszek, Wylamowska Cecylia, Żygenda Władysław. Katalog nazwisk pomordowanych wieńczy napis: „Cześć ich pamięci”. Poza tym na terenie parafii Słup w miejscowości Słupski Młyn znajduje się pomnik - miejsce pamięci z napisem: „Obelisk ten upamiętnia męczeństwo Polaków pomordowanych w okolicznych lasach przez okupanta hitlerowskiego".

\section{Tło historyczne}

Miejscowość Słup, z której wywodzi się sługa Boży Jan Lesiński, jest jedną z parafii dekanatu radzyńskiego, który wchodzi w obszar terytorialny diecezji toruńskiej, a przed jej utworzeniem w 1992 roku znajdował się w diecezji chełmińskiej. Pozostałe parafie tego dekanatu to: Radzyń Chełmiński, Bursztynowo, Gruta, Linowo, Lisnowo, Okonin, Rywałd i Świecie nad Osą. Duchowieństwo Kościoła chełmińskiego, do którego przynależał sługa Boży ks. Jan Lesiński, stanowiło zróżnicowaną strukturę społeczną. Podobnie jak mieszkańcy Pomorza duchowni wywodzili się z polskich i niemieckich rodzin. Przez okupanta byli uznawani za część tzw. grupy przywódczej, dlatego podjęto wobec nich działania w ramach Intelli- 
genzaktion. Działania Niemców wobec osób duchownych charakteryzowały się szczególną bezwzględnością i okrucieństwem na płaszczyźnie ideologiczno-narodowościowej. Germanizacja Pomorza w odniesieniu do osób duchownych polegała na wyłączeniu ich z duszpasterstwa przez eliminację fizyczną, wysyłanie do obozów koncentracyjnych i wysiedlanie. W parafiach pozostawali tylko ci księża, którzy nie zakłócali lub nie stawiali oporu wobec polityki germanizacyjnej. Największe represje w diecezji chełmińskiej - zazwyczaj z nieuzasadnionych powodów - przypadły na jesień 1939 roku. W latach 1940-1945 aresztowania i wezwania na policję były związane jedynie z konkretnymi sytuacjami i należały do rzadkości ${ }^{4}$. Męczeńska droga kleru diecezji chełmińskiej z czasów drugiej wojny światowej w dużym uproszczeniu według ks. Jana Walkusza przebiegała następująco: duchowni z okolic Gdyni, Kartuz, Wejherowa i Pucka przebywali przez krótki czas w więzieniach w tych poszczególnych miastach, a następnie przez więzienie w Gdańsku-Nowym Porcie, komanda rolne, doprowadzani byli do obozu koncentracyjnego w Stutthofie. Podobnie było w innych częściach diecezji, jednak drugi etap nie prowadził już do Gdańska, poza nielicznymi przypadkami, ale do specjalnych obozów przesiedleńczych. Znajdowały się one w Kamieniu Krajeńskim - dla aresztowanych z okolic Kamienia, Sępólna i Tucholi; w Zamartem - dla kapłanów z rejonu chojnickiego; w Górnej Grupie w klasztorze Werbistów osadzano księży z okolic Świecia; w Chełmnie w klasztorze Sióstr Miłosierdzia byli księża z Chełmna, Wąbrzeźna i okolic; w Forcie VII w Toruniu znajdowali się księża z Torunia i tego regionu; w Oborach i Grudziądzu osadzano więźniów z regionu lubawskiego, nowomiejskiego i brodnickiego, a do Działdowa trafiali duchowni z południowo-wschodnich krańców ówczesnej diecezji chełmińskiej5.

${ }^{4}$ Por. Z. Girzyński, Towarzysze męczeńskiej drogi bł. ks. Wincentego Stefana Frelichowskiego. Losy duchowieństwa diecezji chełmińskiej w latach 1939-1945, Toruń 2005, s. 33-38.

5 Por. J. Walkusz, Z zagadnień martyrologii duchowieństwa diecezji chełmińskiej, w: M. Biskup (red.), Z przeszłości diecezji chełmińskiej 1243-1992. Materiały konferencji naukowej w Toruniu, 6 XI 1993 r., Toruń 1994, s. 107. 


\section{Biogram ks. Jana Lesińskiego}

Sługa Boży ks. Jan Lesiński urodził się 11 lipca 1908 roku we wsi Słup, zmarł 7 lutego 1940 roku w Stutthofie. Sakrament chrztu świętego otrzymał w parafii pw. Wniebowzięcia Najświętszej Maryi Panny w Grucie 19 lipca 1908 roku. Rodzicami chrzestnymi Jana byli Tomasz Słupski oraz Marianna Słupska z Dąbrówki Królewskiej ${ }^{6}$. Sługa Boży był synem Franciszka i Anastazji Słupskiej. Rodzice ks. Jana prowadzili gospodarstwo rolne we wsi Słup. Ojciec urodził się w 1850 roku, zmarł 12 maja 1934 roku, a matka urodziła się 26 września 1868 roku, a zmarła 24 sierpnia $1941 \mathrm{roku}^{7}$. Jan był najmłodszym z siedmiorga dzieci. Jego siostry Helena i Teofila wstąpiły do Zgromadzenia Sióstr Miłosierdzia św. Wincentego à Paulo i służyły w szpitalach. Helena posługiwała w Poznaniu, a Teofila w Bydgoszczy. Obie spoczywają w Chełmnie ${ }^{8}$. Pozostałe rodzeństwo to: Jadwiga (ur. 29 grudnia 1898 roku - zm. 20 grudnia 1975 roku w Grucie), Anna (ur. 20 lutego 1902 roku - zm. 8 stycznia 1977 roku w Słupie), Maria (ur. 11 maja 1904 roku - zm. 10 maja 1982 roku w Grudziądzu) i Elżbieta (ur. 18 listopada 1906 roku - zm. 25 grudnia 1983 roku w Grudziądzu) ${ }^{9}$. Jadwiga i Anna wyszły za mąż za braci Górskich z Gruty - pierwsza z nich za Władysława, a druga za Konstantego. Obie ślubowały w lipcu 1921 roku. Maria wyszła za mąż za Antoniego Wacławskiego z Grudziądza.

${ }^{6}$ Por. Świadectwo Chrztu Jana Lesińskiego (Gruta 1908/61), Biblioteka Szkoły Podstawowej im. ks. Jana Lesińskiego w Słupie.

7 Por. Opis do zdjęć, Archiwum Szkoły Podstawowej im. ks. Jana Lesińskiego w Słupie, s. 1.

8 Zgromadzenie Sióstr Miłosierdzia św. Wincentego à Paulo podaje następujące dane odnośnie do sióstr ks. Lesińskiego, które wstąpiły do ich wspólnoty: 1) s. Helena Lesińska - ur. 1 maja 1889 roku w Słupie, ochrzczona 5 maja 1889 roku w Grucie, wstąpiła do zgromadzenia 12 sierpnia 1911 roku, pierwsze śluby złożyła 15 sierpnia 1916 roku, zmarła w Chełmnie 22 lutego 1961 roku; 2) s. Teofila Lesińska - ur. 26 kwietnia 1893 roku w Słupie, ochrzczona 29 kwietnia 1893 roku w Grucie, wstąpiła do zgromadzenia 2 sierpnia 1917 roku, pierwsze śluby złożyła 4 sierpnia 1922 roku, zmarła w Chełmnie 19 grudnia 1976 roku. Por. Zgromadzenie Sióstr MiŁosierdzia św. Wincentego À Paulo, List do p. Janiny Łagoda, 04.06.2002, Archiwum Szkoły Podstawowej im. ks. Jana Lesińskiego w Słupie.

9 Por. Opis..., dz. cyt. 
Elżbieta pozostała stanu wolnego, była od 1945 roku do emerytury naczelnikiem poczty w Grucie ${ }^{10}$.

Ksiądz Jan Lesiński był absolwentem gimnazjum w Grudziądzu, a następnie Wyższego Seminarium Duchownego w Pelplinie, gdzie 15 czerwca 1935 roku przyjął sakrament święceń w stopniu prezbitera. Swoją pierwszą Eucharystię celebrował 18 czerwca 1935 roku w parafii pw. Wniebowzięcia Najświętszej Maryi Panny w Grucie . Na swoim obrazku prymicyjnym umieścił dwa cytaty z Pisma Świętego. Pierwszy z nich pochodzi z Księgi Psalmów: „Panie! Naucz mnie czynić wolę Twoją” $(143,10)$, a drugi to modlitwa: „O Jezu, bądź wyrazem mej wdzięczności! Błogosław tym, którzy doprowadzili mnie do Twego świętego ołtarza”. Jego pierwszą placówką duszpasterską była parafia pw. Najświętszego Serca Pana Jezusa w Grudziądzu. Następnie latem 1939 roku ${ }^{11}$ został mianowany wikariuszem parafii pw. Świętej Rodziny w Gdyni-Grabówku. Jako duszpasterz szczególną opieką otaczał młodzież, dla której organizował liczne wyjazdy, obozy czy biwaki.

Aresztowano go dwukrotnie - pierwszy raz 13 września 1939 roku w charakterze zakładnika na dziesięć dni, a drugi raz 2 listopada 1939 roku, osadzono go wówczas w więzieniu w Nowym Porcie w Gdańsku, skąd przeniesiony został 18 stycznia 1940 roku do obozu koncentracyjnego w Stutthofie, gdzie był pomocnikiem zduna ${ }^{12}$. Według Jana Szilinga przebieg aresztowania i późniejszy los ks. Lesińskiego był następujący: aresztowano go 14 września 1939 roku wraz z proboszczem parafii Gdynia-Grabówek i po nocy, którą spędził w obozie Victoria Schule, został skierowany z innymi więźniami do prac porządkowych na Westerplatte. Następnie przeniesiono go 27 września 1939 roku do obozu Danzig Neufahrwasser, a stamtąd następnego dnia skierowany został do prac rolnych na Żuławach. Ponownie wrócił do Danzig Neufahrwasser 20 listopada 1939 roku, a od 18 stycznia 1940 roku przebywał w obozie

10 Por. J. WacŁawski, List do Dyrekcji Szkoły Podstawowej w Słupie, 10.09.2006, Archiwum Szkoły Podstawowej im. ks. Jana Lesińskiego w Słupie.

11 Ksiądz Wiesław Mazurowski podaje, że ks. Lesiński rozpoczął posługę w Gdyni-Grabówku w kwietniu 1938 roku. Por. W. Mazurowski, Życie oddali za wiarę. Kapłani pelplińscy - męczennicy II wojny światowej, Pelplin 2010, s. 57.

12 Por. Patron szkoły, http://spslup.gruta.pl/?page_id=23 (odczyt z dn. 25.05.2020 r.). 
Stutthof ${ }^{13}$. W Dziejach duszpasterstwa w parafii Świętej Rodziny w Gdyni w latach 1931-1994 znajduje się informacja, że oprócz ks. Lesińskiego i ks. Alfonsa Wysieckiego (proboszcza w latach 1936-1939) aresztowany został tego dnia ze wspomnianej parafii również prefekt ks. Józef Szarkowski ${ }^{14}$.

Ksiądz Wojciech Gajdus, wspominając Stutthof, zaświadcza, że „pomocnikiem zduna, naprawiającego stare piece i budującego nowe, był niezapomniany śp. ks. Jasiu Lesiński, wikariusz z Grudziądza-Tarpna, nasza pierwsza krwawa ofiara męczeńska w Stutthofie"15. Został zastrzelony w Stutthofie, ale dostępny materiał dowodowy w tym zakresie nie pozwala jednoznacznie i szczegółowo odtworzyć tego wydarzenia. Według jednych świadectw ks. Lesiński miał zginąć w nocy z wtorku na Środę Popielcową 7 lutego 1940 roku około godziny 2.30, gdy wychodząc z bloku, nie zawołał do strażnika: Bitte, austreten!. Wówczas miał otrzymać postrzał w klatkę piersiową $\mathrm{z}$ wieży wartowniczej. Według tej wersji rano znaleziono jego ciało na zewnątrz baraku. Inne świadectwa podają, że został zastrzelony z bardzo bliskiej odległości, broniąc się przed niemoralnymi czynami oprawcy ${ }^{16}$. Ksiądz Wojciech Gajdus, jako naoczny świadek wydarzeń, obszernie opisuje, co działo się w obozie po śmierci ks. Jana: „Lotem błyskawicy rozchodzi się po obozie wieść o mordzie. Kto i dlaczego zamordował kapłana? Nazwiska mordercy pewnie się na tym świecie nie ustali. Wsiąkło ono, wobec braku świadków, w gąszcz nocy. (...) Stan ubrania, położenie zmarłego i kierunek kul rewolwerowych dowodziły, że ks. Jana Lesińskiego napadło jakieś dzikie, anormalne zwierzę, i że napadnięty bronił się zajadle w obronie czystości i niepokalaności swego człowieczeństwa. Zwierzę to nie uszanowało nawet i trupa. Broń w obozie nosili tylko oficerowie i strażnicy z formacji elitarnej führera: SS i gestapo. Odnieśliśmy go do kostnicy. Nieśliśmy go,

${ }^{13}$ Por. J. Sziling, Męczeństwo - stużba - walka. Duchowieństwo diecezji chełmińskiej w latach drugiej wojny światowej (1939-1945), Toruń 2019, s. 137.

${ }^{14}$ Por. Dzieje duszpasterstwa w parafii Świętej Rodziny w Gdyni w latach 1931-1994, Tczew 1995, https://swrodzina.diecezja.gda.pl/z_zycia_parafii.htm\#_ftn153 (odczyt $\mathrm{z}$ dn. 12.09.2020 r.).

${ }_{15}$ W. Gajdus, Nr 20998 opowiada, Pelplin 2001, s. 117.

${ }^{16}$ Por. Jan Lesiński, https://pl.wikipedia.org/wiki/Jan_Lesi\%C5\%84ski (odczyt z dn. 04.06.2020 r.). 
jak się odnosi z pola bitwy sztandar pułkowy, skrwawiony, przedziurawiony kulami, lecz zwycięski. Smutek z utraty drogiego towarzysza mieszał się z dumą, że staliśmy się godni, by wśród nas żył i umierał męczennik. Wieczorna nasza modlitwa kończyła się tego dnia słowami prośby: «Janie Lesiński, módl się za nami». Przez kilka dni następnych padał śnieg. Zakrył on czerwone krople krwi błyszczące w słońcu jak rubiny, które mówiły o wierności aż do śmierci, owe rubiny, na które spoglądaliśmy w zadumie"17. Waldemar Rozynkowski w opracowaniu dotyczącym bł. Stefana Wincentego Frelichowskiego przywołuje wspomnienia biskupa chełmińskiego Bernarda Czaplińskiego (1908-1980), który mówi zarówno o ks. Stefanie, jak i o ks. Janie. Biskup - więzień obozu - wyznaje w 1947 roku: „Po zamordowaniu śp. x. Lesińskiego w Stutthofie Wicek powiedział do nas: «Nie za pomordowanych, ale do umęczonych braci naszych powinniśmy się modlić!». Korzystam z jego wskazówki i do niego modlę się w ciężkich swych chwilach, a jestem przekonany, że właśnie za jego u Boga wstawiennictwem niejedną łaskę już otrzymałem. My wszyscy, których droga szła z Wickiem przez obozy koncentracyjne, powinniśmy wobec wszystkich dać świadectwo cichego, lecz wielkiego i świętego jego życia" ${ }^{18}$. Ksiądz Lesiński został pochowany 13 lutego 1940 roku w zbiorowej mogile na cmentarzu na Zaspie w Gdańsku ${ }^{19}$.

\section{Proces beatyfikacyjny ks. Lesińskiego}

Ojciec święty w Liście apostolskim Tertio millennio adveniente przypomina, że Kościół zawsze czcił pamięć męczenników oraz szerzył ich kult. Papież dodaje, że „,z czasem rozwinęła się praktyka kanonizacji, która do dziś trwa w Kościele katolickim i w Kościołach prawosławnych. Kanonizacje i beatyfikacje bardzo się pomnożyły w dzisiejszych czasach. Świadczą one o żywotności Kościołów lokalnych. (...) Największym hoł-

${ }^{17}$ W. Gajdus, Nr 20998..., dz. cyt., s. 138.

18 W. Rozynкowski, Radosnym Panie! O bł. ks. Stefanie Wincentym Frelichowskim (1913-1945), http://www.torun.salezjanie.pl/galeria/g/1415frelich_konkurs/3.pdf (odczyt z dn. 04.06.2020 r.).

${ }^{19}$ Por. W. Mazurowski, Życie..., dz. cyt., s. 62. 
dem dla Chrystusa ze strony wszystkich Kościołów na progu trzeciego tysiąclecia będzie ukazanie przemożnej obecności Odkupiciela w owocach wiary, nadziei i miłości złożonych przez ludzi tylu języków i ras, którzy poszli za Chrystusem różnymi drogami chrześcijańskiego powołania"20. Ksiądz Jan Lesiński oczekuje na wyniesienie na ołtarze w tzw. drugiej grupie męczenników II wojny światowej. Biskup pelpliński Jan Szlaga (1940-2012) wyznaczył ks. Wiesława Mazurowskiego odpowiedzialnym za gromadzenie dowodów heroicznej świętości szesnastu kapłanów diecezji pelplińskiej i jednego kleryka - męczenników II wojny światowej $w$ tzw. drugim procesie beatyfikacyjnym ${ }^{21}$. Pierwszy $z$ tych procesów, tzw. włocławski - rozpoczęty we Włocławku 26 stycznia 1992 roku - obejmował ofiary hitlerowskiego nazizmu z okresu wojny. W historii Kościoła w Polsce był to największy pod względem formuły i liczby kandydatów na ołtarze proces. Obejmował on biskupów, kapłanów, zakonników i zakonnice oraz wiernych świeckich z siedemnastu diecezji, ordynariatu polowego oraz dwudziestu jeden zgromadzeń zakonnych. $\mathrm{W}$ procesie tym nie uwzględniono jednak kapłanów męczenników $\mathrm{z}$ terenu dawnej diecezji chełmińskiej (obecnie diecezja pelplińska), którzy złożyli największą daninę krwi spośród duchowieństwa polskiego. Są to księża: Antoni Aramus, Jan Hamerski, Cyryl Karczyński, Konstantyn Krefft, Anastazy Kręcki, Reginald Krzyżanowski, Jan Lesiński, Bernard Łosiński, Józef Mańkowski, Franciszek Nogalski, Paweł Prabucki, Stefan Radtke, Józef Rozkwitalski, Edmund Roszczynialski, Piotr Sosnowski, Henryk Szuman oraz kleryk Bernard Jaruszewski ${ }^{22}$.

\section{Sługa Boży we wspomnieniach}

Na podstawie zebranych materiałów Wiesław Mazurowski zaświadcza, że jako duszpasterz ks. Lesiński realizował wolę Bożą w postawie serdeczności i otwartości na kontakty z ludźmi. Charakteryzowała go

20 TMA 37.

21 Por. J. Szlaga, Przedmowa, w: W. Mazurowski, Życie..., dz. cyt., s. 5.

22 Por. A. Żur, Żywoty znaczone krwią. Proces beatyfikacyjny męczenników diecezji pelplińskiej, „Pielgrzym” 21 (1994), s. 14, 16. 
dobroć i radość w czasie katechezy, przygotowania wiernych do sakramentów czy podczas rozwijania działalności chóru parafialnego oraz katolickich stowarzyszeń młodzieży. Odznaczał się gorliwością w zakresie nauczania religii w gdyńskiej Szkole Gospodarczej i Handlowej, w której posługiwał ${ }^{23}$. We wspomnieniach osób, które znały ks. Jana zachował się on jako człowiek wielkiego serca, pogody ducha i humoru. Troszczył się o ludzi, lubił przebywać z młodzieżą, dla której organizował wycieczki i obozy, oraz rozwijał działalność katolickich stowarzyszeń przeznaczonych dla młodzieży ${ }^{24}$. Siostrzeniec ks. Lesińskiego tak o nim pisze w liście do dyrekcji Szkoły Podstawowej w Słupie: „Lubiłem przebywać w jego towarzystwie, gdyż był niezmiernie kontaktowy, tak dla dzieci, jak i dorosłych. Dlatego w moich opisach rodzinnych, jak i zbiorze zdjęć ksiądz Jan Lesiński zajmuje poczesne miejsce"25.

\section{Nadanie imienia Szkole Podstawowej w Słupie}

Szkoła Podstawowa w Słupie otrzymała imię ks. Jana Lesińskiego na podstawie Uchwaly Nr XXX/173/06 Rady Gminy Gruta $z$ dnia 15 września 2006 roku. Wybór patrona szkoły był decyzją rodziców i nauczycieli, a głównym jego powodem był związek ze środowiskiem lokalnym, z którego wywodził się ks. Jan ${ }^{26}$. Wybór ten uzasadniono następująco: „Jesteśmy przekonani, że obranie patrona wzmocni funkcję wychowawczą szkoły, pomoże wytyczyć nowe cele, utrwali więzi łączące wspólnotę nauczycieli, wychowanków i rodziców, a także środowiska ze szkołą. Ponadto pomoże budować właściwy świat wartości w naszej małej lokalnej ojczyźnie. Wiele zadań wychowawczych i dydaktycznych realizowanych z uczniami odtworzy historię przedwojennego Słupa"27. Drugim kandydatem na

${ }^{23}$ Por. W. Mazurowski, Życie..., dz. cyt., s. 58.

${ }^{24}$ Por. Ksiądz Jan Lesiński - patron Szkoły Podstawowej w Stupie, Archiwum Szkoły Podstawowej im. ks. Jana Lesińskiego w Słupie.

25 J. WacŁawski, List do Dyrekcji Szkoły Podstawowej w Słupie, 28.08.2006, Archiwum Szkoły Podstawowej im. ks. Jana Lesińskiego w Słupie, s. 2.

26 Por. Ksiadz..., dz. cyt.

27 Wybór patrona, Archiwum Szkoły Podstawowej im. ks. Jana Lesińskiego w Słupie. 
patrona szkoły w Słupie był Bolesław Chrobry. Rada Rodziców licząca sześć osób oraz Rada Pedagogiczna licząca osiem osób w wyniku głosowania oddała głosy w następującej proporcji: na Bolesława Chrobrego cztery głosy, a na ks. Lesińskiego - dziesięć głosów ${ }^{28}$. Szkoła Podstawowa w Słupie nosi imię ks. Jana Lesińskiego od dnia 14 czerwca 2007 roku. Podczas upamiętnienia jednej z rocznic nadania imienia szkole ówczesna jej dyrektor Regina Sadowska mówiła: „Wybór tego kapłana na patrona naszej szkoły to jedna z najważniejszych decyzji, jaką podjęliśmy my, pedagodzy oraz Rada Gminy. Nasz duchowny do dziś pozostaje uosobieniem najważniejszych ludzkich i chrześcijańskich wartości”29. Warto też w tym miejscu oddać głos siostrzeńcowi ks. Jana - Henrykowi Górskiemu, który w liście do dyrektor szkoły tak odniósł się do nadania imienia ks. Lesińskiego wspomnianej placówce: „Jestem przekonany, że nadanie imienia księdza Lesińskiego SP w Słupie stanowi godny sposób uczczenia pamięci tego prawdziwego patrioty i człowieka wielkiej wiary. Mam nadzieję, że przykład księdza Jana stanie się inspirujący dla młodych Polaków - uczniów Pani szkoły"30.

Zapisy Statutu Szkoly Podstawowej w Stupie obowiązującego od 1 grudnia 2017 roku stanowią: „Szkoła posiada własny sztandar i hymn oraz ceremoniał” ${ }^{31}$ oraz: „Hymn szkoły jest elementem ceremoniału szkolnego i śpiewany jest na uroczystościach szkolnych" ${ }^{32}$. Autorem tego hymnu jest Barbara Bratko, a muzykę skomponowały Beata Czmoch i Barbara Bratko. Załacznik do Statutu Szkoły stanowi: „W szkole obowiązuje podczas uroczystości szkolnych obok hymnu państwowego hymn szkoły" ${ }^{33}$. Treść hymnu szkolnego jest następująca:

${ }^{28}$ Protokół w sprawie wyboru patrona szkoły, 23.06.2006, Archiwum Szkoły Podstawowej im. ks. Jana Lesińskiego w Słupie.

29 RAS, Słup - Dzień Patrona Szkoły, „Głos Gruty” 6 (2012), s. 4.

30 H. Górski, List do Pani mgr Reginy Sadowskiej Dyrektor Szkoły Podstawowej $w$ Słupie, 25.08.2006, Archiwum Szkoły Podstawowej im. ks. Jana Lesińskiego w Słupie.

31 Statut Szkoły Podstawowej im. ks. Jana Lesińskiego w Stupie, http://spslup.gruta.pl/ wp-content/uploads/2020/08/nowy-statut-1.pdf (odczyt z dn. 21.09.2020 r.).

32 Tamże, $\$ 1.11$.

${ }_{33}$ Załącznik nr 1 do Statutu. Ceremoniał szkolny z wykorzystaniem sztandaru w Szkole Podstawowej im. ks. Jana Lesińskiego w Słupie, Biblioteka Szkoły Podstawowej im. ks. Jana Lesińskiego w Słupie. 
1. Zapał ma i silną wolę każdy z nas, piątki, szóstki zdobywać w szkole jest już czas, więc się nie martw, mój kolego, gdyż patrona masz takiego, który wzorem i przykładem dla nas jest.

Ref. On człowiekiem był dobroci i humoru, wielkie serce i pogodę ducha miał.

On urodził się wśród nas, na wędrówki chodził w las, w naszej małej, kochanej ojczyźnie.

2. Jeśli tak naprawdę masz wszystkiego dość, śpiewaj z nami, a w kąt zaraz pójdzie złość.

Nie martw się i podnieś głowę,

bo już wiesz, bo już gotowe, aby z ks. Jana w życiu przykład braćs

Uroczystość nadania imienia szkole składała się z dwóch części: celebracji Eucharystii w kościele św. Anny w Słupie pod przewodnictwem pierwszego biskupa toruńskiego Andrzeja Wojciecha Suskiego oraz programu artystycznego przygotowanego przez społeczność szkolną. Uroczystość została poprzedzona szkolnym konkursem wiedzy o ks. Janie Lesińskim oraz rozprowadzaniem cegiełek w parafii w Słupie z przeznaczeniem na sztandar szkoły. Pamiątką tego wydarzenia jest również Księga Gości, w której znajduje się m.in. wpis urodzonego w Słupie ks. Piotra Neumanna następującej treści: „ «Tu wszystko się zaczęło» (JP II). Gratuluję wyboru Patrona - dumny jestem z postawy Ziomków, iż wracamy do korzeni naszych Ojców. Niech nasz (pozwolę sobie użyć tego zwrotu, jako absolwent tej Szkoły) Patron umacnia wiarę i nadzieję naszą, iż ostatecznie zwycięża miłość. Przekazujmy i brońmy tych wartości, za które ks. Jan oddał życie - historia potwierdziła, iż one są nieprzemijające"35.

${ }^{34}$ Hymn Szkoły Podstawowej im. ks. Jana Lesińskiego w Stupie, w: Załącznik nr 1 do Statutu. Ceremoniat szkolny z wykorzystaniem sztandaru w Szkole Podstawowej im. ks. Jana Lesińskiego w Słupie, Biblioteka Szkoły Podstawowej im. ks. Jana Lesińskiego w Słupie.

35 P. Neumann, Gratuluję wyboru Patrona, w: Księga Gości, 14.06.2007, Biblioteka Szkoły Podstawowej im. ks. Jana Lesińskiego w Słupie, s. 4. 


\section{Upamiętnienie ks. Lesińskiego w szkole w Słupie}

Od czasu nadania patrona szkole jej przedstawiciele i uczniowie zawożą kwiaty i znicze na grób ks. Lesińskiego, który znajduje się na cmentarzu na Zaspie w Gdańsku ${ }^{36}$. W głównym holu Szkoły Podstawowej w Słupie pamięć ks. Lesińskiego jest uczczona przez gablotę pamiątkową, sztandar i portret oraz tablicę pamiątkową. Na tablicy pamiątkowej umieszczono popiersie ks. Lesińskiego, nad którym widnieje zapisany wielkimi literami napis: „Bądź dobry ponad wszystko”, a pod nim (również wielkimi literami): „Ksiądz Jan Lesiński, 1908-1940, polski męczennik, patriota. Synowi tej ziemi - przyjaciele szkoły, 14 czerwca 2007 roku”. Nad lewym górnym rogiem tablicy pamiątkowej znajduje się godło Polski. Portret ks. Lesińskiego ze słupskiej szkoły jest autorstwa p. Lewandowskiego. Został ofiarowany szkole przez siostrzenice ks. Jana - Bernadetę Czecholińską i Aleksandrę Czecholińską. Pod nim umieszczono papieskie błogosławieństwo o treści: „Ojciec Święty Benedykt XVI udziela całym sercem Apostolskiego Błogosławieństwa Nauczycielom i Uczniom Szkoły Podstawowej w Słupie z okazji nadania imienia ks. Jana Lesińskiego i przekazania sztandaru 14 czerwca 2007 roku, wzywając obfitości łask Bożych i opieki Matki Najświętszej”. Błogosławieństwo potwierdził swym podpisem 8 maja 2007 roku w Watykanie abp Oscar Rizzato. Rewers sztandaru szkoły stanowi biały orzeł w złotej koronie na czerwonym tle, awers zawiera wizerunek patrona. Napisy na sztandarze podane są wielkimi literami: rewers - Bóg Honor Ojczyzna, awers - Szkoła Podstawowa im. ks. Jana Lesińskiego w Słupie. Sztandar obszyty jest złotymi frędzlami. Gablota pamiątkowa zawiera następująco opisane zdjęcia:

- zdjęcia rodziców ks. Jana: ojciec - Franciszek Lesiński, matka Anastazja, z domu Słupska,

- zdjęcia rodzeństwa ks. Jana: s. Helena, s. Teofila, Anna Górska z domu Lesińska, Jadwiga Górska z domu Lesińska, Maria Wacławska z domu Lesińska, Elżbieta Lesińska,

36 Por. W. Wielgoszewski, Ocalić od zapomnienia. Duchowni diecezji chełmińskiej XIII-XX wiek, Toruń 2019, s. 234-235. 
- zdjęcia z uroczystości rodzinnych

- z odpustu z 26 lipca 1939 roku w domu rodzinnym ks. Jana w Słupie,

- z 15 sierpnia 1939 roku z odpustu w Grucie,

- z uroczystości prymicyjnej w czerwcu 1935 roku w Grucie

u siostry księdza Jadwigi Górskiej,

- inne zdjęcia

- pobyt w Seminarium Duchownym w Pelplinie

w latach 1930-1935,

- otwarcie remizy strażackiej w Grudziądzu-Tarpnie

w 1937 roku,

- neoprezbiterzy z 1935 roku,

- ks. Jan Lesiński w ogrodzie seminaryjnym,

- ks. Józef Koszałka, nauczycielka Joanna Tadeuszewska, ks. Jan Lesiński,

- ks. Jan Lesiński z rodziną: z mamą Anastazją

i rodziną siostry Anny w Słupie,

- ks. Jan Lesiński przed okrętem Batory,

- ks. Jan na ulicy w Gdyni,

- mały Janek z siostrami: Heleną, Teofilą, Anną,

- Jan Lesiński - zdjęcie z książeczki wojskowej

z 64. Pułku Piechoty,

- dwa zdjęcia obrazków prymicyjnych,

- wspomnienie ks. Wiesława Mazurowskiego zatytułowane Sługa Boży Jan Lesiński.

Dla upamiętnienia ks. Jana Lesińskiego co roku w czerwcu w szkole w Słupie świętowana jest rocznica nadania imienia szkole. Przypomina się wówczas uczniom, kim był ks. Lesiński i dlaczego został wybrany na patrona szkoły. Uczniowie szkoły biorą udział w wycieczkach szkolnych, wśród których są również wyjazdy do Stutthofu - miejsca śmierci ks. Jana. Należy podkreślić, że już po zakończeniu wojny podjęto starania, by upamiętnić ks. Jana Lesińskiego. Ówczesny proboszcz parafii w. Świętej Rodziny w Gdyni wraz z wiernymi modlił się za ks. Jana. Jego imię widnieje również wśród nazwisk pomordowanych księży gdańskich na tablicy pamiątkowej, która umieszczona jest na frontowej ścianie 
kościoła pw. Najświętszego Serca Pana Jezusa w Gdyni. Fotografia umieszczona w zakrystii kościoła w Grudziądzu-Tarpnie stanowi upamiętnienie jego zasług w pracy duszpasterskiej i męczeńskiej śmierci ${ }^{37}$.

\section{Zakończenie}

W Liście apostolskim Tertio millennio adveniente papież stawia bardzo jasną tezę: „W naszym stuleciu wrócili męczennicy. A są to często męczennicy nieznani, jak gdyby «nieznani żołnierze» wielkiej sprawy Bożej. Jeśli to możliwe, ich świadectwa nie powinny zostać zapomniane w Kościele" ${ }^{38}$. Obowiązkiem współczesnych chrześcijan - zgodnie z wolą ojca świętego - jest zatem, „ażeby Kościoły lokalne, zbierając konieczną dokumentację, uczyniły wszystko dla zachowania pamięci tych, którzy ponieśli męczeństwo"39. Samo jednak zbieranie dokumentacji bez ożywiania pamięci o tych wielkich świadkach wiary jest bezcelowe. Niniejszy artykuł stanowi tylko cząstkę realizacji zadania wyznaczonego przez św. Jana Pawła II. Ufam jednak, że przybliżone w nim życie i śmierć ks. Jana Lesińskiego pokazują czytelnikowi, jak pięknie żyć i jak godnie umierać. Wysiłki podejmowane przez społeczność Szkoły Podstawowej w Słupie dla upamiętnienia ich patrona są żywym ewoluującym pomnikiem pamięci. Sama zaś uroczystość nadania imienia szkole, jak i codzienne wysiłki ludzi pracujących i uczących się w słupskiej szkole, by naśladować tego sługę Bożego, są pięknym połączeniem przeszłości z teraźniejszością oraz odważnym patrzeniem w przyszłość z ufnością, że życie i śmierć ks. Jana Lesińskiego wydadzą dobre owoce. Ufam również, że niniejszy artykuł będzie zachętą do poznawania i ukazywania szerszemu gronu postaci lokalnych męczenników, którym jesteśmy winni ocalenie ich od zapomnienia, a jednocześnie stanie się motywacją do pielęgnowania przez czytelników tych wartości, za które sługa Boży Jan Lesiński oddał swe młode życie.

\footnotetext{
37 Por. W. Mazurowski, Życie..., dz. cyt., s. 62.

38 TMA 37.

39 Tamże.
} 


\section{Bibliografia}

Dzieje duszpasterstwa w parafii Świętej Rodziny w Gdyni w latach 1931-1994, Tczew 1995, https://swrodzina.diecezja.gda.pl/z_zycia_parafii.htm\#_ ftn153 (odczyt z dn. 12.09.2020 r.).

Gajdus W., Nr 20998 opowiada, Pelplin 2001.

Girzyński Z., Towarzysze męczeńskiej drogi bł. ks. Wincentego Stefana Frelichowskiego. Losy duchowieństwa diecezji chetmińskiej w latach 1939-1945, Toruń 2005.

Górski H., List do Pani mgr Reginy Sadowskiej Dyrektor Szkoły Podstawowej $w$ Stupie, 25.08.2006, Archiwum Szkoły Podstawowej im. ks. Jana Lesińskiego w Słupie.

Historia Parafii, „Gazetka parafialna” 26.07.1999, s. 2.

Hymn Szkoły Podstawowej im. ks. Jana Lesińskiego w Stupie, w: Załacznik nr 1 do Statutu. Ceremoniat szkolny z wykorzystaniem sztandaru w Szkole Podstawowej im. ks. Jana Lesińskiego w Stupie, Biblioteka Szkoły Podstawowej im. ks. Jana Lesińskiego w Słupie.

Jan Lesiński, https://pl.wikipedia.org/wiki/Jan_Lesi\%C5\%84ski (odczyt z dn. 04.06.2020 r.).

Jan Paweł II, List apostolski Tertio millennio adveniente, Rzym 1994.

Ksiądz Jan Lesiński - patron Szkoły Podstawowej w Stupie, Archiwum Szkoły Podstawowej im. ks. Jana Lesińskiego w Słupie.

Mazurowski W., Życie oddali za wiarę. Kapłani pelplińscy - męczennicy II wojny światowej, Pelplin 2010.

Miszewski W. (red.), Diecezja Toruńska. Spis parafii i duchowieństwa. Rok 2002, Toruń 2002.

Neumann P., Gratuluję wyboru Patrona, w: Księga Gości, 14.06.2007, Biblioteka Szkoły Podstawowej im. ks. Jana Lesińskiego w Słupie.

Opis do zdjęć, Archiwum Szkoły Podstawowej im. ks. Jana Lesińskiego w Słupie. Patron szkoły, http://spslup.gruta.pl/?page_id=23 (odczyt z dn. 25.05.2020 r.).

Protokół w sprawie wyboru patrona szkoły, 23.06.2006, Archiwum Szkoły Podstawowej im. ks. Jana Lesińskiego w Słupie. 
RAS, Słup - Dzień Patrona Szkoły, „Głos Gruty” 6 (2012), s. 4.

Rozynkowki W., Radosnym Panie! O bt. ks. Stefanie Wincentym Frelichowskim (1913-1945), http://www.torun.salezjanie.pl/galeria/g/1415frelich_konkurs/3.pdf (odczyt z dn. 04.06.2020 r.).

Statut Szkoły Podstawowej im. ks. Jana Lesińskiego w Stupie, http://spslup. gruta.pl/wp-content/uploads/2020/08/nowy-statut-1.pdf (odczyt z dn. 21.09.2020 r.).

Sziling J., Męczeństwo - służba - walka. Duchowieństwo diecezji chetmińskiej w latach drugiej wojny światowej (1939-1945), Toruń 2019.

Szlaga J., Przedmowa, w: W. Mazurowski, Życie oddali za wiarę. Kapłani pelplińscy - męczennicy II wojny światowej, Pelplin 2010, s. 5.

Świadectwo Chrztu Jana Lesińskiego (Gruta 1908/61), Biblioteka Szkoły Podstawowej im. ks. Jana Lesińskiego w Słupie.

Wacławski J., List do Dyrekcji Szkoły Podstawowej w Stupie, 28.08.2006, Archiwum Szkoły Podstawowej im. ks. Jana Lesińskiego w Słupie.

Wacławski J., List do Dyrekcji Szkoły Podstawowej w Stupie, 10.09.2006, Archiwum Szkoły Podstawowej im. ks. Jana Lesińskiego w Słupie.

Walkusz J., Z zagadnień martyrologii duchowieństwa diecezji chetmińskiej, w: M. Biskup (red.), Z przeszłości diecezji chełmińskiej 1243-1992. Materiały konferencji naukowej w Toruniu, 6 XI 1993 r., Toruń 1994, s. 103-118.

Wielgoszewski W., Ocalić od zapomnienia. Duchowni diecezji chełmińskiej XIII-XX wiek, Torun 2019.

Wybór patrona, Archiwum Szkoły Podstawowej im. ks. Jana Lesińskiego w Słupie. Załącznik nr 1 do Statutu. Ceremoniat szkolny $z$ wykorzystaniem sztandaru w Szkole Podstawowej im. ks. Jana Lesińskiego w Stupie, Biblioteka Szkoły Podstawowej im. ks. Jana Lesińskiego w Słupie.

Zgromadzenie Sióstr Miłosierdzia św. Wincentego à Paulo, List do p. Janiny Łagoda, 04.06.2002, Archiwum Szkoły Podstawowej im. ks. Jana Lesińskiego w Słupie.

Żur A., Żywoty znaczone krwią. Proces beatyfikacyjny męczenników diecezji pelplińskiej, „Pielgrzym” 21 (1994), s. 14, 16. 
Ks. Dawid Galanciak - doktor nauk teologicznych, absolwent Wydziału Teologicznego Uniwersytetu Mikołaja Kopernika w Toruniu, kapłan diecezji toruńskiej - wikariusz parafii pw. św. Katarzyny Aleksandryjskiej w Łasinie, katecheta w Zespole Szkół Ponadpodstawowych im. Kazimierza Jagiellończyka w Łasinie. Dziedziny zainteresowań: katechetyka, metodyka nauczania. 